\title{
タンパク質とイオンとの相互作用 筋肉収縮時のイオンの役割を含めて一
}

$\mathrm{Na}$ と K, $\mathrm{Ca}$ と $\mathrm{Mg}$ を鋭く見分けられるということは, 生物が生物として存在しう る基盤の中で, 最も重要なものの一つである. 神経の機能も, 筋肉の収縮も, みなこの基 盤の上に立っている，この性質は，誰しも予想すると接り，その大部分がタンパク質に依 存することは，疑いを入れない，他方，タンパク質とイオンとの関係は，合成高分子電解 質に対する研究方法で処理しらる面のあることも事実である. しかし，だからといって， そういったアプローチを精密化することによって, 問題が解決すると思ったら, あまりに も，生き物を見くびったことになろう，タンパク質は，まだ完全には，化学的物質になり きっていないようである.

\section{江 橋 節 郎*}

\section{1.はじめに}

タンパク質とイオン相互作用は，普通の高分子電解 質と低分子イオンの相互作用として考兄られる面と, そのような一般的な説明で性理解し党ない面とがあ る; 前者も生物現象の基礎として重要な意味をもつこ とは当然であるが，生物学的立場からは，後者のよう な事例の方に，多くの関心がもたれるのは当然のこと であろう。このシリーズに和ける他の執筆者は，いず れも高分子の物理化学の専門家であり, 格調高い論文 をるのされることと思らので, 本態不明の生物的な問 題を扱った本稿は、シリーズ中の息抜きと考兄ていた だきたい。

生きている細胞の特徵の一つは, 外環境と異なった イオン組成をるちうることである. たと艺部分の 動物の細胞形質は，Na を主成分とする外液（高等動 物では血浆特よびリンパ液, 海産の下等動物では海そ のものがこれにあたる。）と異なり，Kを主成分とし ている. 神経機能の基盤をなしている電気現象は, こ

* Setsuro EBASHI 東京大学（医学部薬理学教室, 理学部物理学教室(併任) 113 東京都文京区本郷 7-3-1）教授・医博

Interaction of Protein and Ions with Particular Reference to the Role of Ion in Muscle Contraction.
の内外のイオン分布の違いを巧みに利用したものであ る.また，大部分の細胞内部には， $\mathrm{Mg}$ は高濃度に存 在するにもかかわらず，遊離の $\mathrm{Ca}$ イオンの濃度はゼ 口に近い，後述するように，筋の収縮に Ca が引き金 物質として用いられるのも，細胞のこの基礎的な性質 に根拠を拉くものである.

このよらに， $\mathrm{Na}$ と $\mathrm{K}, \mathrm{Mg}$ と $\mathrm{Ca}$ 鋭く見分け る性質——それは生命の基本的な性質の一つであるが 一が，それに関与するタンパク質のイオンに対する 特異的な親和性に依存することは当然予想されること である，以下そのような実例の二，三をあげて，生物 というもののからくり，あるいはやり口といったもの を探ってみたいと思う。

\section{2. タンパク質とアルカリイオンの相互作用}

細胞がその内外に異なったイオン環境をるつために は，Naを追い出し，Kを取り込むという，いわゆる $\mathrm{Na} \cdot \mathrm{K}$ ・能動輸送と呼ばれる機能をるたなければなら ない，これは，湾とえどすべての動物細胞に共通な機 能であり, 細胞が生きているといらことの一つの重要 な指標である.この機能が形質膜に存在する，いわゆ る Na・K-ATPase といら一種の酵素によって行なわ れているということは，いまや異論の余地がない：現 在考兄られているところでは，この酵素は形質膜の構 
成分として存在し，第 1 表のスキームに示されるよう な機構で, $\mathrm{Na}$ と $\mathrm{K}$ の能動輸送が行なうものとされ ている1). もちろんこのスキームは確定的のものでな いが，重要なことは， $\mathrm{Na}^{+}$特よび $\mathrm{K}^{+}$に対する親和

第 1 表 Na・K-ATPase の機構を示すスキーム

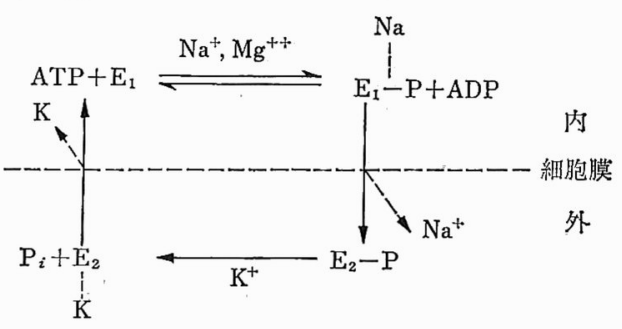

第 2 表 $\mathrm{K}^{+}$活性化䣼素

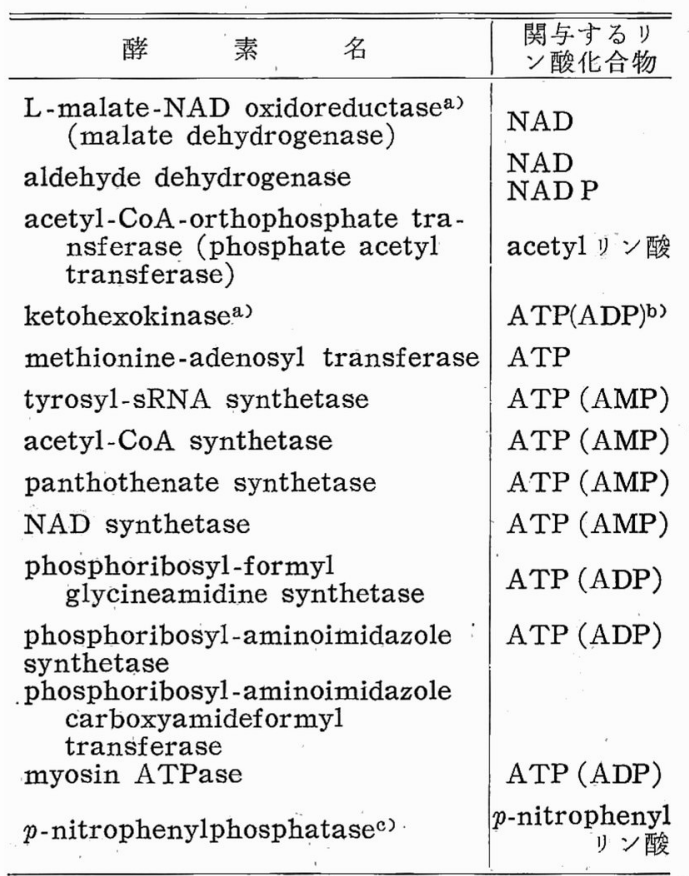

a) $\mathrm{K}^{+}$がなくてむある程度活性がある醇奖

b) カッコ内は ATP の転化物を示す

c) 本文参照

性が基質である ATP との反応の過程に括いてのみ 見られ，ATP の存在しない場合の酵素艺のものは， これらのイオンに対し，なんら特殊な親和性をるって いないことである（もっともこの 親和性は kinetics そよって指摘されたもので，結合が直接証明されたも のではない).

このようそ， Na・K-ATPase はきわめて特異な性 質をもつ酵素として，他の酵素から別格視されがちで ある. しかし，酵素群を調べてゆくと， Na と K を 区別することのできる酵素がいくつがあることに気づ くであるう. (第 2 表). こういった酵素は，次のよう
な特徴をもっている.

i ) $\mathrm{K}^{+}, \mathrm{Rb}^{+}, \mathrm{NH}_{4}{ }^{+}$が 著明な 活性化作用を示す $\left(\mathrm{NH}_{4}{ }^{+}\right.$が最も著明な作用を示すことが多い).

ii ) $\mathrm{Na}^{+}$は汪とんど活性化作用を示さないばかりで なく， $\mathrm{K}^{+}$などによる活性化作用を原則として抑 制する（Li ${ }^{++}$はわずかながら活性化作用のある '場合が多い).

iii）基質または補酵素として，高エネルギーリン酸 結合を含む化合物が関与している.

このようにKから Naを区別でさるといらことは， この種の酵素が $\mathrm{Na}$. K-ATPase - 一部分, 第 1 表の スキーム12に拈いて，左半分と共通の性質をもつもの と考觉ることがでる、このことが，単なる偶然の一 致でないことは, Na K-ATPase（あるいはこれと わかちがたく結合した酵素）が $p$ かトロフェニルリ ン酸を分解し，その際のイオンとの関係が上記の酵素、 群と全く一致するといら事実によってある程度裏づけ られよう。

以上のような酵素作用にみられるイオン特異性の基 礎となるタンパク構造を明らかにすることは，生物学 の立場から重要，かつ魅力的な課題である.た沉し， 第 3 表にみるよらに，このよらな性質がすべての基質 について成立するのではなく，特殊な基質に挌いての み見いだされることは，その基本となる構造もしく は，反応がきわめて微妙なものであろらことを示唆す るもので，単純な物理化学的解析で究明しらるものと

第 3 表 Na·K-ATPase 阽よびミオシン ATPase の基質特異性

Na·K-ATPase K-EDTA $ミ$ オシンATPasea

\begin{tabular}{lll}
\hline ATP & $(1)$ & $(1)$ \\
GTP & $\sim 0$ & 0 \\
ITP & $\sim 0$ & 0 \\
CTP & 0.23 & 0.37 \\
UTP & $\sim 0$ & 0.13
\end{tabular}

a) K による活性化は $\mathrm{Mg}$ によって妨害されるので EDTA を 加えた条件下で測定する

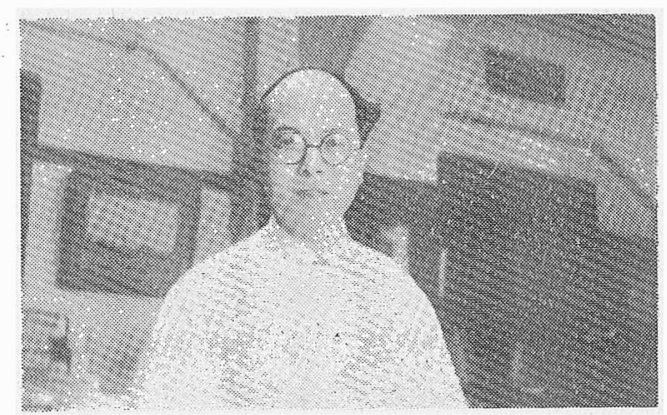

江橋節郎氏 昭和19年東京大学医学部医学科卒業. 専門分野 は基礎医学. 現在，筋収縮弛緩に関する研究に從事. 
は思われない。

ミオシンについては，アルカリイオンとの結合性が 測定されているが，予想ど物り，

$$
\mathrm{Li}>\mathrm{Na}>\mathrm{K}>\mathrm{Rb}
$$

といらような系列が得られているが，とうてい酵素作 用に怙けるイオンの特異性を説明しらるよらなデータ ではない。これも第 3 表の結果から考党れば，当然の ことであろう.

最後に一言られて招かなければならないのは，脂 質，とくにリン脂質の問題である，細胞膜に括ける脂 質の役割が重要であることはいらまでもないが，こ のことからイオンの選択性をリン脂質に求めようと する考克方も少なくない.このことに関して最近, 抗生物質中の一つのグループとしてのイオノフォア (ionophore)一一細胞膜の脂質と結合してイオンの透 過性を選択的，非選択的に増加させる一古注目され 㤝じめ，脂質の役割がより強調されるようになった。 しかしこのことはイオンの選択性を脂質だけがにな らといらことを意味するものでないことは，いらまで もない.

、な括これに関連して，イオノフォアによる選択的透 過性は，アルカリイオンについてい衤ば，今のところ

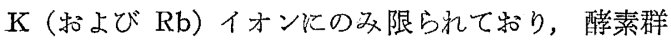
の場合とよく一致する。このことから明らふなら に，Na に関する問題は，どうも純粋タンパク系や人 工系では試験管内で再現されているとはいいがたい. その意味では，第 1 表の右半分の反応は，生物の神 秘性をともかくも残した領域であるといらことができ る. Na に関しては，脂質の関与といらことが，ある いはより重要であるといらことかもしれない。

\section{3. アルカリ土類イオンと酵素作用}

アルカリイオンに見られたよらな現象が，アルカリ 土類イオンについて多認められる. むしろ酵素作用に は 2 洒イオンを必要とするものが普通である. これK 二つの場合のあることがわかる.

i ）基質とコンプレックスをつくる場合一すなお ち，イオンと狭義の基質のコンプレックスが真の 意味での基質である場合である，リン酸化合物が 基質として働く場合は，ことに高エネルギーリン 酸結合をもつ化合物の場合では，ほとんどすべ て，Mg を必要とするが，これはこのケースにあ てはまる。

ii）基質と醉素のコンプレックスが特定のアルカリ 土類イオンに親和性をもつ場合一 $\mathrm{Na} \cdot \mathrm{K}$-ATPase に対比される Ca-ATPase（すなわち筋小胞体の $\mathrm{Ca}$ のくみ上げ機構) の場合がそれであって, $\mathrm{Mg}$
·ATP の存在下にのみ $\mathrm{Ca}$ に対する親和性が生ず る. しかし,このことは; $\mathrm{Ca}$ の結合点が必ずしも 酵素活性部分と異なるといらことを意味しない. 以上いずれの場合も基本的にはアルカリイオンの場 合と同じように䤃素-基質複合体の問題でありタン パク質自体のイオン親和性は基本的には意味をもたな いといらことである.

\section{4. 生物的に意義をもつタンパク質とアルカリ 土類イオンの結合—トロポニンの $\mathbf{C a}$ 結合}

はしがきにも述べたように，筋の収縮の直接の誘起 物質は Caである. 神経から筋細胞に化学的物質によ って伝えられた情報は，筋細胞膜で再び動作電位と呼 ばれる電気的現象(興奮現象)となり，この電気的影響 が, Ca の貯溜槽である筋小胞体 (3. ii) 参照) から の $\mathrm{Ca}$ の遊離をきたす。この $\mathrm{Ca}$ が収縮系に作用す るのであるが, この際 $\mathrm{Ca}$ は, 収縮タンパク質といわ れるミオシン, アクチッのいずれかに作用するのでな く,アクチンフィラメント上に存在するトロポニンと いらタンパク質に作用し，これからの情報が，卜ロポ ミオシンを介してアクチンに伝えられ，ここに二つの 主要収縮タンパクの相互作用が起こるものであること が明らかにされてきた2゙.

今少し詳しく述べると，アクチンフィラメントは 第1図のよらな構造をしていると考光られる.トロポ 一ンは，直接アクチンにはつかず，アクチンに親和性 をもつ繊維状タンパク質トロポミオシンの上に存在す る. 現在考光られているところでは， Ca の存在しな いときは，トロポニン*1はトロポミオシンを介してア クチンフィラメントにミオシンフィラメントとの反応 が起こりにくいような制御をかけている. (藤目. 石 渡3゙ルよれば，アクチンフィラメント全体が異常にか たくなった状態にあるという. また Huxley ら4ねよ れば， $\mathrm{Ca}$ の存在しないときに起こるトロポニンのコ ンホメーションが，トロポミオシンの位置をわずかに

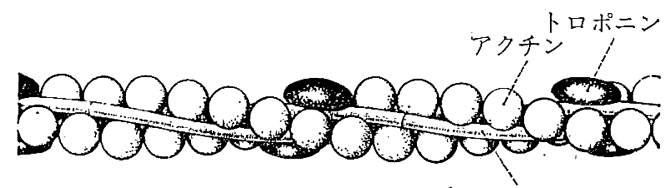

トロポミオシン

$10 \mathrm{~nm}$

第 1 図 縕いフィラメントの模型図 アクチンフィラメントとトロポニソ,トロポミお シンの立体的関係を示求。

*1 トロポニンは現在分子量 $17000 ， 22000 ， 38000$ の三つの成分からな ることが示され，このららトロポニンAと称される分子量 17000 の 成分が $\mathrm{Ca}$ に強い親和性をむち， Ca の脱着により著明なコンホ メーションの変化を起こすことが明らかになっている. 
ずらし，アクチンがミオシンと結合する部分を立体的 にじゃましているのだという)、トロポニンに Ca が 結合すると卜ロポニン分子炕構造変化が起こりトロポ ミオシンを介してアクチンに与兄られていた抑制が除 かれる（藤目，石渡によればアクチンフィラメントは 柔軟性を回復するという。 また Huxley らによれば, トロポミオシンがミオンンとの反応をじゃましない位 置にひささがることになる).このように間接的な手 法によって生きた筋の収縮系の制御が行なわれている わけである。あらかじめ抑制をかけ，それをはずすこ とによって活性化を行ならこと火は，広く生物界飞見 られる現象であり，瞬時に応答しなければならない機 能には適した方法であるには違いない，

予期されたことであるが，卜ロポニンの Ca 飞対 する親和性はきわ放めて特異的なるので，第 4 表に示す ように Mn，Co， Ni などの遷移金属にはほとんど親 和性がない，EDTA などのキレート物質は遷移金属 に対して，Ca などによりはるか滈い結合定数をむ つことはよく知られたことであり，カルボキシル基拉 よびアミノ基を配位子とすると考光られるタンパク質 が，そらいったキレート剤と著しく異なった行動をと ることは，一般的には考光にくいことである。事実多 くのタンパク質は EDTA ほどではなくても，アルカ リ土類よりも遷移金属汶して，多少とも高い結合定 数をるつのが普通である.したがってトロポニンがな ぜこのように Ca，Sr にの及高いキレート定数をるつ のかは化学的にも興味のある問題であり, 構造の解明 があたれるところである.

最近，収縮系と同様の低い $\mathrm{Ca}$ 濃度によって活性化 される酵素が知られてきたこれは前節に述べたタイ プの金属親和性と異なりむしろトロポニン型のるの と考觉られる、物そらくそれらの酵素は複合タンパク 質であり，トロポニン様部分が，アロステリックに醉 素活性部分の構造を制御するものと考兄られる。

\section{5. 生理的に重要なタンパク質—イオン相互作 用機構解明へのアプローチ}

以上述べてきたような生物学的に重要なタンパク質 とイオンの相互作用を分子レベルで追求するにはどう したらよいかといらことは，われわれ生物屋にとって も重要な問題である. この点についての成果はいまの ところきわめて微々たるものがある，従来の高分子物 理化学で用いられてきたような手法は，端的にいって あるり有力でなかった。忞机は, 従来の方法が, 分子 全体の平均的な挙動を測るものが多かったからであ り，この系列に属する测定法は，今後いかに精度が增 しても，あまり成果は期待できないであるう。

もちろんどのような方法がよいか，どのような新し
第 4 表 トロポニンの各種 2 価イオンに対する 親和性（結合定数の比）

\begin{tabular}{cc}
\hline \hline $\mathrm{Ca}$ & $(1)$ \\
\hline $\mathrm{Cd}$ & 0.08 \\
$\mathrm{Sr}$ & 0.04 \\
$\mathrm{~Pb}$ & 0.02 \\
$\mathrm{Mn}$ & 0.01 \\
$\mathrm{Co}$ & 0.003 \\
$\mathrm{Ni}$ & 0.002 \\
$\mathrm{Ba}$ & 0.002 \\
$\mathrm{Mg}$ & $<0.001$ \\
$\mathrm{Zn}$ & $<0.001$ \\
\hline
\end{tabular}

い方法が生れてくるだろらかといらことを語る資格は 著者にはない，ただ一ついえることは，形態的にも化 学的にも，なんとかして分子を見るといらことが結局 は王道ではないのだろらか。たと兊ば，タンパク質な らば全構造を決めることがなによりも近道であるよう に見觉る. 最近前述トロポニンの作用機構に関して, 電子顕微鏡像からの影像強化法による三次元再構成法 が，従来の方法になかった成果をあげようとしてい る.この方法自体は，上記のような考穴方から見れ ば，まだ過渡的なるのではあるが，やはり艺の方向を 目ざしたものが成功を収めつつあるという点で注目す ベきであろう.

\section{6. むすび}

以上，アルカリあるいはアルカリ土類イオンに限っ て見ても，タンパク質には化学的に近縁のイオンを識 別する能力があり，それがタンパク質の生理的機能の 基盤となっている場合のあることを示してきた，艺の 機構は次のようなパターンに分けることができよう。

i ）タンパク質自体に特定のイオンに対する親和性 がありそそれがそのままその機能の基礎となっを いるもの一一例, トロポニンの $\mathrm{Ca}$ 結合

ii）酵素としてのタンパク質がその酵素反応過程に 物いて特定のイオンに対し親和性をもつもの.

a) 基質が特定イオンとコンプレックスをつくっ て初めて真の基質となりらる場合一一例，リン 酸関係酵素々 $\mathrm{Mg}$

b ）基質と酵素のコンプレックスないし中間体が 特定のイオンに対し，親和性をるつ場合一 例，能動輸送 ATPase

文献

1) R. W. Albers : Annu. Rev. Biochem., 36, 727 (1967)

2) S. Ebashi, M. Endo, I. Ohtsuki : Quart. Rev. Biophys., 2, 351 (1969)

3) S. Ishiwata, S. Fujime :J. Mol. Biol., 67, 1 (1972)

4) T. Wakabayashi, H. E. Huxley : 私信 